\title{
Lymphoma Cell to Lymphocyte Ratio Measurement
}

National Cancer Institute

\section{Source}

National Cancer Institute. Lymphoma Cell to Lymphocyte Ratio Measurement. NCI

Thesaurus. Code C74910.

The determination of the ratio of lymphoma cells compared to lymphocytes present in a sample. The measurement may be expressed as a ratio or percentage. 